\title{
Applying Density and Hotspot Analysis for Indigenous Traditional Land Use: Counter-Mapping with Wasagamack First Nation, Manitoba, Canada
}

\author{
Keshab Thapa, Shirley Thompson \\ Natural Resources Institute, University of Manitoba, Winnipeg, Treaty 1 Territory, Manitoba, Canada \\ Email: thapak@myumanitoba.ca, s.thompson@umanitoba.ca
}

How to cite this paper: Thapa, K., \& Thompson, S. (2020). Applying Density and Hotspot Analysis for Indigenous Traditional Land Use: Counter-Mapping with Wasagamack First Nation, Manitoba, Canada. Journal of Geoscience and Environment Protection, 8, 285-313.

https://doi.org/10.4236/gep.2020.810019

Received: May 18, 2020

Accepted: October 27, 2020

Published: October 30, 2020

Copyright $\odot 2020$ by author(s) and Scientific Research Publishing Inc. This work is licensed under the Creative Commons Attribution International License (CC BY 4.0).

http://creativecommons.org/licenses/by/4.0/

Open Access

\begin{abstract}
Traditional land-use studies display specific locations used and occupied by Indigenous Peoples in their ancestral lands to sustain their land-based livelihoods. Indigenous communities use these maps to reclaim their territories by demonstrating their current land-use and occupancy that extends vast distances beyond their reserves. To support the protection of ancestral territory against the threats of resource extraction by outsiders, we applied the density and hotspot mapping approaches to display the concentrated land use areas of 49 harvesters of Wasagamack First Nation in Manitoba, Canada. In contrast to the conventional land use mapping, which presents the land use areas as points or spots on the map, density and hotspot mapping shows areas of intensive land use and cultural significance. This paper reinforces Wasagamack Anishininews' view that their entire ancestral territory is sacred and vital to the Wasagamack First Nation and supports their case for their traditional territory's self-governance. If integrated with Wasagamack Anishininews' community development goals, the density and hotspot mapping approach can facilitate land use planning for sustainable conservation of important areas for the well-being of Wasagamack First Nation.
\end{abstract}

\section{Keywords}

Density and Hotspot Mapping, Indigenous Self-Determination, Anishininew, Colonialism, Mino Bimaadiziwin

\section{Introduction}

The United Nations Declaration on the Rights of Indigenous Peoples (UNDRIP) 
has affirmed the rights of Indigenous Peoples for self-determination through self-government of their ancestral lands (United Nations, 2008). Indigenous Peoples' relationship is deeply spiritual, with their land relationship, akin to kinship (Wilson, 2008; Collins \& Thompson, 2017; Imbong, 2018; Simura \& Mudimu, 2019; Thompson et al., 2019). Indigenous Peoples were bestowed by the Creator the responsibility to steward their ancestral land (Wilson, 2008). This land defines Indigenous identity and is the basis of Indigenous language, culture, ceremonies, and good life (Ballard et al., 2019; Joseph, 2018; McGregor, 2018). Indigenous community members define the importance of their ancestral land in this paper, providing a counter-map that challenges the occupation of Indigenous territory by government and industry in Canada (McIlwraith \& Cormier, 2016).

In Manitoba, Canada, Mino Bimaadiziwin is the term used by Anishininew People in the Island Lake region to describe the practice of a good life in their mother tongue, Anishinimowin (Thompson et al., 2019). Anishininew Peoples consider every area in their territory to be sacred as prayers of their ancestors have occurred for thousands of years, on many occasions, including the harvest of wildlife (Thompson et al., 2019; Wojtuszewska, 2019). Oppositely, the traditional land/territory of the Anishinew to colonial governments has significance mainly for economic exploitation and boosting the Canadian economy. Thus, resource extraction on Indigenous lands typically benefits settler societies, but the negative impacts befell Indigenous Peoples living there (Tauli-Corpuz et al., 2018; Thompson, Pritty, \& Thapa, 2020; Zurba et al., 2019).

To date, limited analysis of traditional land-use methods has occurred regarding modeling or analyzing land-use points (Mcllwraith \& Cormier, 2016). We modeled traditional Indigenous land use data in Island Lake, Manitoba, Canada, for 49 Wasagamack First Nation people, by using density and hotspot mapping. This challenges colonial governments' underestimation of traditional land use areas from specific sites (Tobias, 2010) by expanding harvesting and cultural sites into the larger areas of hotspot and density maps. As Canadian law and policy has a colonial legacy, the conservation and use of ancestral territory by Indigenous Peoples have received little attention in Canada (McGregor, 2018; Thompson, Pritty, \& Thapa, 2020; Zurba et al., 2019). Canadian governments have used mapping as a tool to colonize Indigenous Peoples. However, participatory mapping with Indigenous Peoples integrates Indigenous land use and occupancy into the GIS mapping approach. These participatory maps provide a valuable tool to protect Indigenous culture, language, and territories (Wojtuszewska, 2019).

This paper explores traditional land use mapping literature to discover its role in Indigenous land claims and its potential in environmental impact assessment against resource extraction on ancestral land. A historical context of Canada's Treaties and the Indian Act is then discussed regarding their role in limiting Indigenous land access. The need for land based reconciliation is argued. The me- 
thod outlines point data is mapped according to the intensity and concentration of use, to create different theme maps. This approach to traditional land use mapping challenges colonial governments' underestimation of traditional land use by individual points (Tobias, 2010) by applying modeling to expand harvesting and cultural sites into hotspot and density maps. In the discussion section, we ask how traditional land use mapping and this analysis can further land-based reconciliation and decolonization in Canada. Finally, we consider whether modeling Indigenous traditional land use offers a meaningful scientific way to apply traditional land use mapping points for defending territory, after discussing policies required to decolonize the land.

\subsection{Traditional Land Use Studies}

Traditional land-use studies are used by Indigenous communities to map their story of the use of land and resources in their traditional territory (Olson et al., 2016). Canadian governments have used mapping to make Indigenous Peoples' stories and land invisible on maps by redefining traditional territories with settler names, towns, and industries. In empire-building, maps became tools of conquest. However, integrating Indigenous land use and occupancy into the GIS mapping approach has been applied to protect Indigenous culture, language, and territories (Wojtuszewska, 2019). These land-use and occupancy studies counter-map Indigenous territory to contest settler or industrial development in the court system (Freeman, 2011; McIlwraith \& Cormier, 2016). In the Inuit Land Use and Occupancy Project, Inuit used mapping to reclaim sovereignty of the Northwest Territories through comprehensive land claims (Freeman, 2011). With the integration of Indigenous community members' experiences, traditional land use studies show the land's significance for local people's livelihoods and culture to protect against the threat of unwanted development (McIlwraith \& Cormier, 2016).

Different studies have provided some limited analysis and modeling of Indigenous harvest and cultural sites. Thompson, Pritty and Thapa (2020) used land use data from 30 harvesters and the trapline administrative area and a radius of $14.25 \mathrm{~km}$ around moose hunt sites to estimate the foodshed area for Garden Hill First Nation. A similar foodshed analysis was carried out for Wasasgamack First Nation with the data from 49 harvesters (Thompson, Thapa, \& Whiteway, 2019; Thompson, Harper, \& Whiteway, 2020). In 34 Inuit communities in the Northwest Territories and northern Yukon, the Inuit Land Use and Occupancy project prepared individual map biographies and composite maps to map areas for hunting, trapping, fishing, camping, ceremonial sites, burial grounds, and other areas of historical significance (Freeman, 2011). In the Ouje-Bougoumou Cree communities in James Bay, Quebec, Tsuji et al. (2007) prepared 14 intensity maps and sites of concern, 11 thematic harvesting and gathering maps, and three categories of traplines maps. These three categories were differentiated by settler impacts, including: category one traplines, having no contaminants from min- 
ing; category two traplines, having likely contact to contaminants; and category three traplines, having contamination. In northern Canada, Deh Cho First Nations applied density modeling to land use and occupancy data of 386 land users. These First Nations then negotiated with the Federal government that their ancestral lands be legally protected from resource extraction and recognized as Deh Cho territory (Norwegian \& Cizek, 2004). Berkes et al. (1995) prepared point maps of land use of the Omushkego Cree communities of the Mushkegowuk region in northern Ontario. These maps estimated the communities used around 250,000 square kilometers $(\mathrm{sq} \cdot \mathrm{km}$ ) of the Omushkegowuk traditional territory to fish and hunt geese, caribou, and moose. Counter-mapping and analyzing findings from traditional land use studies can decolonize Indigenous territories and prioritize Indigenous territories for Indigenous-led protection and sustainable use (Olson et al., 2016).

\subsection{Colonial Historical Context}

The historical context of Indigenous land explains the importance of mapping ancestral lands for traditional land use and cultural sites. These maps may become the subject of court battles over land, development, and Indigenous rights. This section considers the impact of treaties and the role of reconciliation on land.

\subsubsection{Treaties and Land}

Before colonization, Indigenous Peoples lived on Turtle Island ${ }^{1}$ as sovereign nations with territories, languages, cultures, spirituality, and institutions (Joseph, 2018). Then the British Crown negotiated access to Indigenous land and territories to expand their colony onto Turtle Island by signing Treaties with Indigenous nations (Indian and Northern Affairs Canada, 1969; Tully, 1999). These Treaties on Turtle Island all promised that Indigenous traditional pursuits in their land and water were to continue "as long as the sun shines, rises, and rivers flow" (Mercredi, 2012: p. 2). However, following the signing, the Canadian government's interpretation of these Treaties was one-sided and has not included Indigenous perspectives, legal tradition, and oral history (Craft, 2011).

Canada has taken the position that Indigenous Nations ceded their land. Canada was taking a similar position in the peace and friendship Treaties before the courts proved them wrong. Canada continues to assert the same for the numbered Treaties. Oppositely, the view of Indigenous Peoples is they agreed in the Treaties to share some of their lands with settlers and did not cede the land or their governance (Borrows \& Rotman, 2018). Indigenous Peoples have a nation-to-nation relationship with Canada as defined by the Royal Proclamation of 1763 and historic Treaties (Canada Royal Commission on Aboriginal Peoples, 1996a; Truth and Reconciliation Commission of Canada, 2015; Tully, 1999), which they retain. So, although the Canadian governments still refute Indigen-

${ }^{1}$ Turtle Island is used to refer to present-day North America. 
ous sovereignty in Canada, Indigenous Peoples remain sovereign nations on Turtle Island.

Settler governments broke the Treaty promises to maximize their land, riches, and power, waging cultural genocide to assimilate Indigenous Peoples into the settler culture and governance (Palmater, 2019). To control Indigenous lands and territories, Canada enforced the Indian Act in 1876, requiring a pass for Indigenous Peoples to go off their reserve and making Indigenous Peoples wards of the state (Joseph, 2018). The Indian Act confined Indigenous Peoples into tiny and unproductive areas called Indian reserves to open up their lands for settlement and development by the Indian Act (Joseph, 2018). The Indian Act outlawed Indigenous languages, ceremonies, and laws (Thapa, 2018). Residential schools and churches were some of the many colonial institutions that applied assimilation policies to undermine Indigenous language, culture, and governance (Borrows \& Rotman, 2018; Truth and Reconciliation Commission of Canada, 2015). The Indian Act still controls the sovereignty, self-government, and self-determination of First Nations (Borrows \& Rotman, 2018).

The Canadian governments favor the welfare of settlers, who are "resource-hungry", and neglect the rights of Indigenous Peoples who have used, occupied, and protected their ancestral territory in their ways (Booth \& Skelton, 2004: p. 80). Colonial institutions are still applying assimilation policies, including the present-day Canadian government officials. They are "legally responsible" for providing services to Indigenous Peoples living on-reserve, even though Indigenous Peoples continue to resist (Palmater, 2019). Indigenous Peoples remain on their lands rather than being assimilated but need recognition of their rights to the land to reclaim Indigenous sovereignty (Ballard et al., 2019; Thompson et al., 2019; Thompson, Pritty, \& Thapa, 2020). Canada's assimilation policies displace Indigenous Peoples from their traditional territories rather than provide services and infrastructures for their Mino Bimaadiziwin (Jane et al., 2018; Palmater, 2019).

Indigenous Peoples in Canada have a "right of governmental autonomy" as occurred before colonialism, and Canadian governments must recognize their "authority" (Canada Royal Commission on Aboriginal Peoples, 1996b: p. 1). Although Canada ratified UNDRIP in 2016, Canada was one of the last to sign. By signing UNDRIP, Canada acknowledges that Indigenous Peoples in Canada have rights to self-determination, rights to self-government, and rights to their traditional territory (Government of Canada, 2017; United Nations, 2008).

\subsubsection{Reconciliation and Land}

Recently in the early twenty-first century, Canada acknowledged the harms and mistakes of colonialism and committed to engaging in a positive process of truth-telling, healing, and reconciliation (Truth and Reconciliation Commission of Canada, 2015). Reconciliation is a process that focuses on streng- 
thening the relationships between settlers and Indigenous Peoples in Canada (Truth and Reconciliation Commission of Canada, 2015). The Canadian government has formally shown its commitment to reconciliation with Indigenous Peoples in different platforms. A recent one is a document entitled "Principles Respecting the Government of Canada's Relationship with Indigenous Peoples":

The government of Canada is committed to achieving reconciliation with Indigenous $[P]$ eoples through a renewed, nation-to-nation, government-to-government, and Inuit-Crown relationship based on recognition of rights, respect, co-operation, and partnership as the foundation for transformative change (Department of Justice Canada, 2018: p. 3).

Despite the Canadian governments' statements on reconciliation and UNDRIP regarding Indigenous rights to their lands and territories, Canada exploits Indigenous territories. It denies First Nations governance and self-determination, in practice. Canada prioritizes the unsustainable development of oil, natural gas, hydropower dams, and mining to provide a resource-based Canadian economy (National Energy Board, 2018). With this focus on resource exploitation of Indigenous territories, such as the Athabasca region, as well as Northern Manitoba's watersheds, Canada colonizes Indigenous land as a "resource extraction zone" (Joly et al., 2018: p. 336).

Canadian legislation facilitates the exploitation of large areas of pristine Indigenous land and water for settlers' priorities. In the Province of Manitoba, for example, through some strategic laws such as the Mining and Minerals Act (1991), the Crown Land Act (1987), and The Planning Act (2005), the Manitoba government controls Indigenous lands and territory (The Crown Lands Act, 1987; The Mines and Minerals Act, 1991; The Planning Act, 2005). Manitoba government permits mineral exploration or quarry withdrawal in Indigenous territories (The Mines and Minerals Act, 1991). Manitoba's Provincial Planning Regulation, also called the Regulation 81/2011, considers mining and mineral extraction activities to be the best use of greenstone belt land (The Planning Act, Provincial Planning Regulation, 2011), which effectively undermines land-based reconciliation. Wasagamack First Nation is struggling to fight against mining in the greenstone belts in their territory.

\subsection{Wasagamack First Nation}

Located around the northwestern shore of Island Lake, Wasagamack is one of the four Anishininew communities (Figure 1) in northeastern Manitoba, Canada (Reynar \& Matties, 2015). Wasagamack Anishiniwuk speak Anishinimowin, which is their mother tongue. Nora Whiteway, an Elder, explained Wasagamack means "the land with bays" in Anishinimowin. Wasagamack does not have direct road access to other communities except through ice roads during winter. The ancestral territory of the Wasagamack Anishiniwuk is vast; however, due to the colonial laws, the Wasagamack First Nation community members are living 


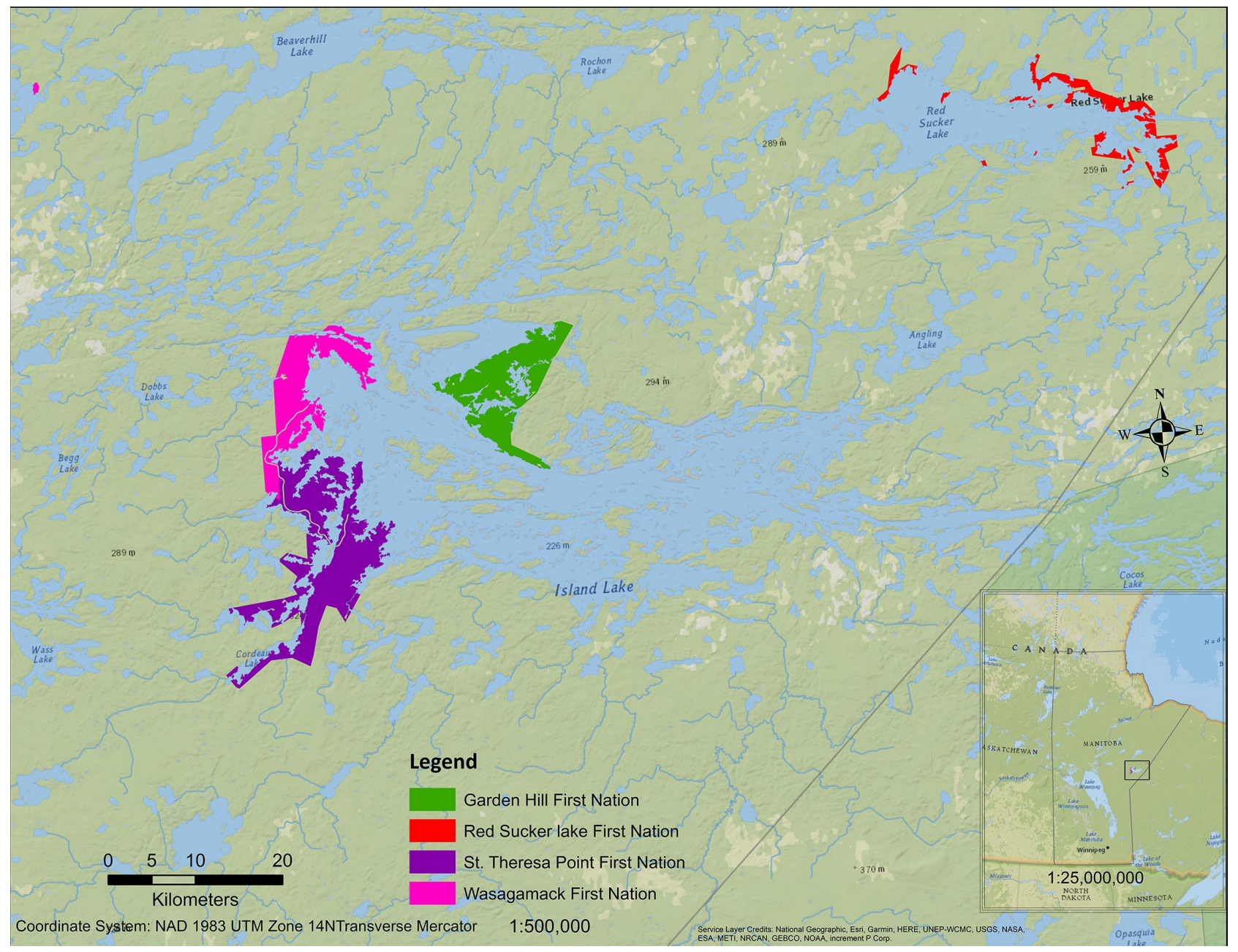

Figure 1. Map of Wasagamack First Nation reserve and other First Nation reserves in Island Lake.

in a small and densely populated reserve (Thompson et al., 2019). The reserve spans 80.91 square kilometers and is now home to a 1405 Anishiniwuk with 285 houses (StatsCanada, 2017). The majority of the houses (225) were single-detached; the average household size of 4.9 showed overcrowding compared to the provincial average of 2.5 and the national average of 2.4 (StatsCanada, 2017).

Wasagamack was in the Keewatin District of the North West Territories before Manitoba formed in 1870 until Manitoba's expansion in 1905 (Library and Archives Canada, 2015). As part of Island Lake Band, Wasagamack became a signatory to an Adhesion to Treaty Five on August 13, 1909 (Indian and Northern Affairs Canada, 1969; Wasagamack First Nation, 2010). During the Treaty signing, the Island Lake Band was represented by Chief George Knott and Councilors Joseph Linklater and John Mason. The Crown was represented by Commissioner John Semmens and witnesses H. S. Stead, Bertha Stead, Barbara Ross, Charles B. Isbester, C. Cunningham, WM. M. McEwen, Walter Ross, and Alex H. Cunningham (Indian and Northern Affairs Canada, 1969). As per the Treaty, the Crown's primary obligations to Island Lake Anishiniwuk were to 
provide adequate lands, ensure local schools for education, ensure hunting and fishing rights in their ancestral territory, provide tools for gardening, and compensate Anishiniwuk for their lands if they share:

Provide 160 acres of land for a family of five or in the proportion for larger or smaller families, ... maintain schools for instruction in reserve, ... pay gratuity of five dollars in cash per person in extinguishment of all claims, ... pay five dollars annuity per head, ... [continue] right to pursue hunting and fishing throughout the tract [that is unoccupied], ... pay sum of five hundred dollars per annum every year in the purchase of ammunition, and twine for nets, supply farming and gardening tools [that includes two hoes, one scythe, one axe and one spade per family, one plough for every ten families, five harrows for every twenty families, and one cross-cut saw, one hand-saw, one pit-saw, the necessary files, one grindstone, and one auger for each band], and compensate for the value of any improvements on the reserves (Indian and Northern Affairs Canada, 1969: para 13, 16, 17, 19, 20, 23, \& 24).

The Island Lake Band included four reserves: Wasagamack, Garden Hill, St. Theresa Point, and Red Sucker Lake. Before the Treaty, the Island Lake community lived on Linklater Island, also known as Old Post (Wasagamack First Nation, 2010). Victor Harper, an Elder of Wasagamack First Nation, shared that, after the Treaty was signed, the Dominion of Canada told the community to relocate to an Island Lake area suitable for farming and raising livestock (Fallding, 2010). In 1913, the community's eleven families moved to the Wasagamack reserves (Wasagamack First Nation, 2010) along the edge of Island Lake to easily access the location's clean drinking water (Fallding, 2010). In 1969, the Island Lake Band got divided into four First Nation communities, each with its Chief and Councilors (Fallding, 2010). Victor Harper, an Elder from Wasagamack First Nation, shared that the key reason for the divide was Christianity (Fallding, 2010); a secondary, yet equally significant, reason was to clear Linklater Island for mining.

\section{Methodology}

\subsection{Research Approach}

The mapping data and interviews were conducted in partnership with Wasagamack First Nation. The funding was from the Social Science and Humanity Research Council (SSHRC) research grant "The Good Life through Indigenous Community Development: Sustainable Development Planning to Build Community Assets in Island Lake First Nation Communities" and the Mino Bimaadiziwin Partnership. Wasagamack First Nation was one of the three community sites in Island Lake, Manitoba, in the project. The land use maps were published in the Journal of Agricultural Food Security and Community Development (Thompson et al., 2019) and a community book (Thompson, Harper, \& Whiteway, 2020).

The research approach was collaborative to ensure that Anishiniwuks' know- 
ledge and needs guided the research. The project had emerged from community Elders wanting to generate evidence of the use and occupancy of ancestral territory by Wasagamack First Nation. The project outputs contribute to re-assert Wasagamack Anishiniwuks' inherent rights to their ancestral land and territory. The research team, led by Victor Harper on the community-side and Dr. Thompson on the university-side, had various meetings with Wasagamack First Nation Chief and Council and Elders. Community coordinators were identified from the initial meetings. The community coordinators were informed about the research and how it would contribute to regaining Anishiniwuks' rights to lands and self-determination. We frequently met frequently to plan how to document their land-use and later share the maps and analysis to get their feedback. The lead author joined the team in the fall of 2016; most of the land use documentation with community members was complete by that time.

This research followed Indigenous ethical principles of Ownership, Control, Access, and Possession (OCAP) of the research data with Wasagamack First Nation. The Wasagamack First Nation community members, through their Chief and Council, have ownership and control over the research data. We have provided all copies of maps and the database to the Chief and Council through hard drives. We are committed to ensuring the "relational accountability" as reinforced by Wilson (2008: p. 99). To ensure relational accountability in an Indigenous research paradigm, Wilson emphasizes that research with Indigenous communities needs to be relevant to the communities. The researchers should also regard community culture and protocol, demonstrate reciprocity, and be responsible for their action and research findings. Besides community approval, this research got approval from the University of Manitoba's Joint Faculty Research Ethics Board. We acknowledge community members' contributions in this research by disclosing their names to acknowledge their knowledge sharing and guidance. Naming community members in research acknowledges their contribution, as endorsed by Indigenous scholars (Kovach, 2009; Lambert, 2014; Smith, 2001; Wilson, 2008). Being non-Indigenous to this Turtle Island, we are co-synthesizing knowledge with community members to share with researchers and policymakers to contribute to decolonize Canada and support Wasagamack First Nation's vision of regaining self-sufficiency and self-government.

\subsection{Land Use Documentation}

The mapping process began in 2013 with a 60-hour long "First Nation Use-and-Occupancy Map Survey Workshop: Research Design and Introduction for Interviewers." Community coordinators from Wasagamack, Garden Hill, and Red Sucker Lake First Nations and researchers from the University of Manitoba participated in this workshop. This workshop developed the land use training manual based on community coordinators' decisions about questions and methods best for their communities. The workshop also then taught the community coordinators to lead the process in their community. This workshop 
also practiced using the base maps for land use documentation and interview community members.

Elder Victor Harper and Elder Norah Whiteway provided guidance and leadership to Johnathan Harper and the University of Manitoba researchers, Dr. Thompson, and students. In total, 49 Wasagamack community members individually were interviewed about where they undertook traditional activities in their traditional territory. Those activities were categorized into seven themes: fishing, trapping, cultural activities, hunting, overnight stay, plant and earth material collection, and birds and eggs harvesting. Interviews with each individual took $3-4$ hours. With an Elder, the research team asked questions and marked the location as pointed by the Elder on the map. The research team asked community members questions, which they answered by stories and marking harvest and cultural sites on maps. We used a topographic base map of the Island Lake region to mark the locations during the interviews. The Chief and Council and community Elders suggested for the selection of community members for interviews.

\subsection{Analysis of Land Use Locations}

The land use locations and the land use types were then entered into excel files to analyze in ArcGIS. Summary of land use maps and thematic land use maps were previously published (Thompson et al., 2019; Thompson, Harper, \& Whiteway, 2020). This paper uses the land use data to analyze the density and hotspots for concentrated land use areas of the 49 harvesters. In ArcGIS online, using the default parameters, we conducted hotspot and density analyses to prepare density maps and hotspot maps of each of the seven thematic land uses and complete land use. The layers generated after the analysis were exported into shape files to import into the ArcGIS desktop version 10.4.1 (North American Datum 1983 (NAD83) Universal Transverse Mercator (UTM) Zone 14 projection system) for preparing customized maps.

\subsubsection{Density Mapping}

Density mapping provides a variable's spatial relationship over the landscape by showing the concentration of points or lines per square unit (ESRI, 2016). We used density mapping to pinpoint the concentration of land uses in the territory of Wasagamack First Nation. The variable, in this case, was the location of land use. Density mapping tools offer line, point, and kernel density functions (CEHI, 2018b).

We used kernel density mapping, which overlays the pattern of changing landscapes from point or line locations (Shafabakhsh et al., 2017). The kernel function creates regular density areas from point data in raster form, allowing for hotspot analysis and interpolation (Krisp et al., 2009). Kernel density maps show circular areas around each feature point to indicate density, such as land use location, by applying the kernel function to each observation (Shafabakhsh et al., 2017). The mathematical equation of kernel density is: 


$$
f(x, y)=\frac{1}{n h^{2}} \sum_{i=1}^{n} K\left(\frac{d_{i}}{h}\right)
$$

where $h$ is the bandwidth, $d_{i}$ is the distance of the variable from the center in the bandwidth, $K$ is the function of the kernel density, $n$ is the number of observations (Shafabakhsh et al., 2017).

\subsubsection{Hotspot Mapping}

Hotspot mapping assesses whether the distribution of the land use spot was random or significant. The null $\left(\mathrm{H}_{0}\right)$ and alternative $\left(\mathrm{H}_{1}\right)$ hypotheses were:

$\mathrm{H}_{0}$ : At a 95\% level of confidence, the distribution of overall and specific land use of 49 Wasagamack community members in their traditional territory was random, i.e., the hotspots were non-significant.

$\mathrm{H}_{1}$ : At a 95\% level of confidence, the distribution was significant, i.e., significant hotspots.

Unlike density mapping, hotspot analysis provides information about the locations that are statistically significant, such as hot and cold spots (CEHI, 2018a; Krisp et al., 2009). The importance of hotspot mapping over density mapping is that density mapping only provides information about the clustering of the points or locations but not whether the clustering is statistically significant (CEHI, 2018a). Hotspot analysis maps the clusters based on the Getis-Ord GI* function and calculation of kernel density (Prasannakumar et al., 2011). Hotspot mapping uses $\mathrm{Z}$-scores and $\mathrm{P}$-values to indicate if the clustering is a significant hotspot (Prasannakumar et al., 2011). For example, a high Z-score and small P-value show a significant hotspot (Prasannakumar et al., 2011). The mathematical equation of the hotspot function is:

$$
G i^{*}(d)=\frac{\sum j W_{i j}(d) x_{j}-W_{i}^{*} \overline{X^{*}}}{S^{*}\left\{\left[\left(n S_{1 i}^{*}\right)-W_{i}^{* 2}\right] /(n-1)\right\}^{1 / 2}}
$$

where " $W_{i j}(d)$ " is a spatial weight vector with values for all cells " $j$ " within a distance " $d$ " of target cell " $\dddot{\eta}$ "; $W_{i}^{*}$ is the sum of weights; $S_{1 i}^{*}$ is the sum of squared weights; and $s^{*}$ is the standard deviation of the data in the cells (Prasannakumar et al., 2011).

\section{Results}

\subsection{Land Use Density Maps of Wasagamack Anishiniwuk}

Figure 2 and Figure 3, respectively, illustrate the overall land use density map and thematic density maps of 49 Wasagamack community members. The density value is for different land-use themes as the minimum and maximum values for each land use per $100 \mathrm{sq} \cdot \mathrm{km}$. The overall density map shows high land use density around Stevenson Lake, Pelican Lake, Bigstone Lake, Gunisao River, Bennett Lake, Makwa Lake, Knight Lake, Stevenson River (Matawkamang), Willow Lake, Fairy Rock Lake, Mainland River, Kitchi Lake, Muskwa Lake, Kal- 
liecahoolie Lake, Amos Lake, and Joint River. The density values in these areas ranged from 575 to 950 land-use sites per $100 \mathrm{sq} \cdot \mathrm{km}$ area. The different thematic land use density maps (Figure 3 ) show a similar land use pattern with the overall land use density map, except birds and eggs harvesting. Land use density of birds and eggs harvesting is much distinct in Kalliecahoolie Lake, Stevenson Lake, Stevenson River, and Bennett Lake.

\subsection{Land Use Hotspot Maps of Wasagamack Anishiniwuk}

Figure 4 and Figure 5, respectively, show the overall hotspot map and thematic hotspot maps of 49 Wasagamack community members. The hotspot map indicates whether the overall (combining all land uses) land use concentrations were random (null hypothesis) or significant (alternative hypothesis). We identified 1110 hotspots, and each hotspot has an area of $2 \mathrm{sq} \cdot \mathrm{km}$. These hotspots represent a minimum of one harvest or site to a maximum of 86 . As each hotspot area is two sq.km, a hotspot with a single land use location can be statistically significant due to the clustering of the location with others in the adjoining hotspots.

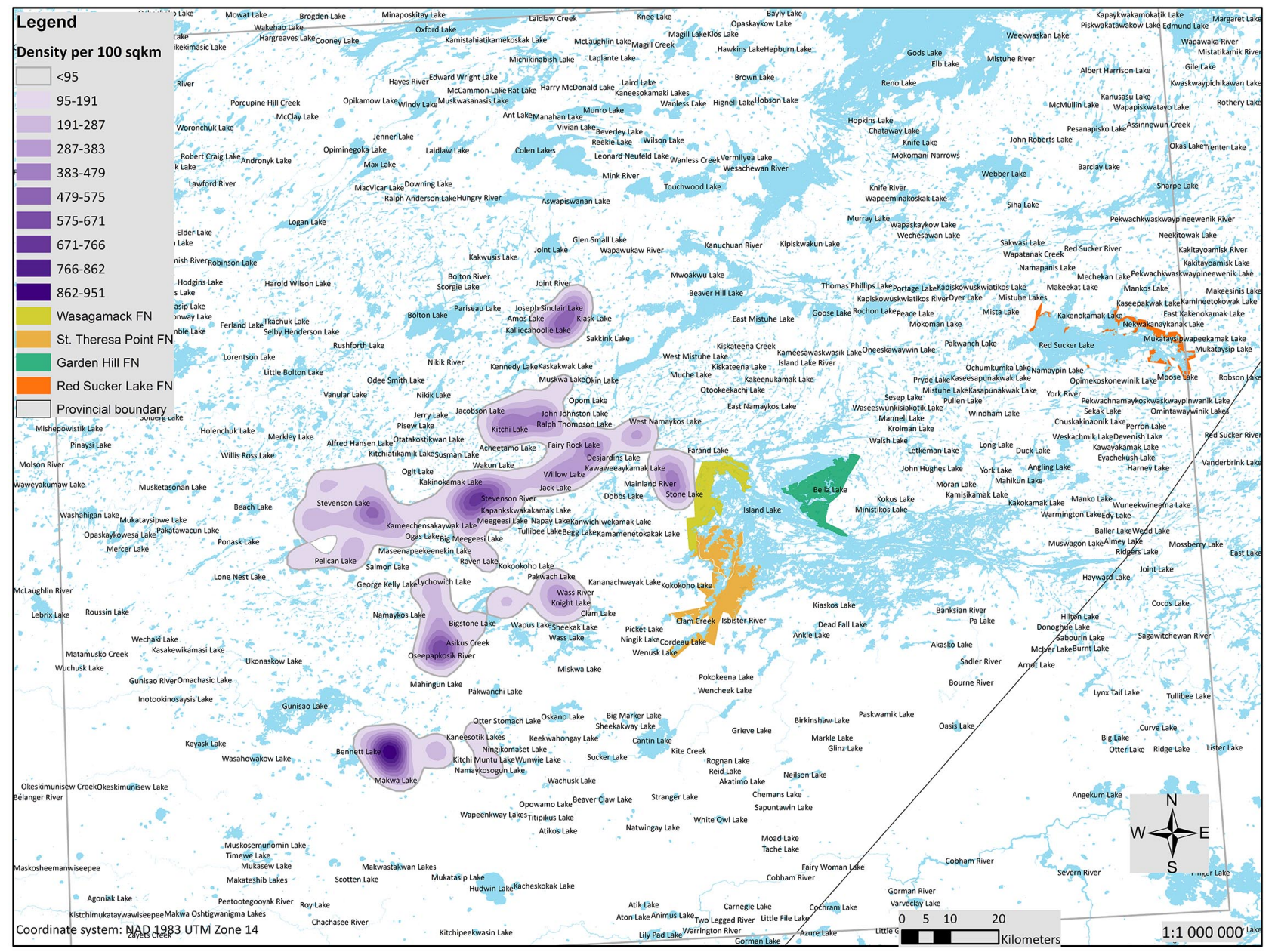

Figure 2. Overall land use density of 49 harvesters of Wasagamack First Nation. 

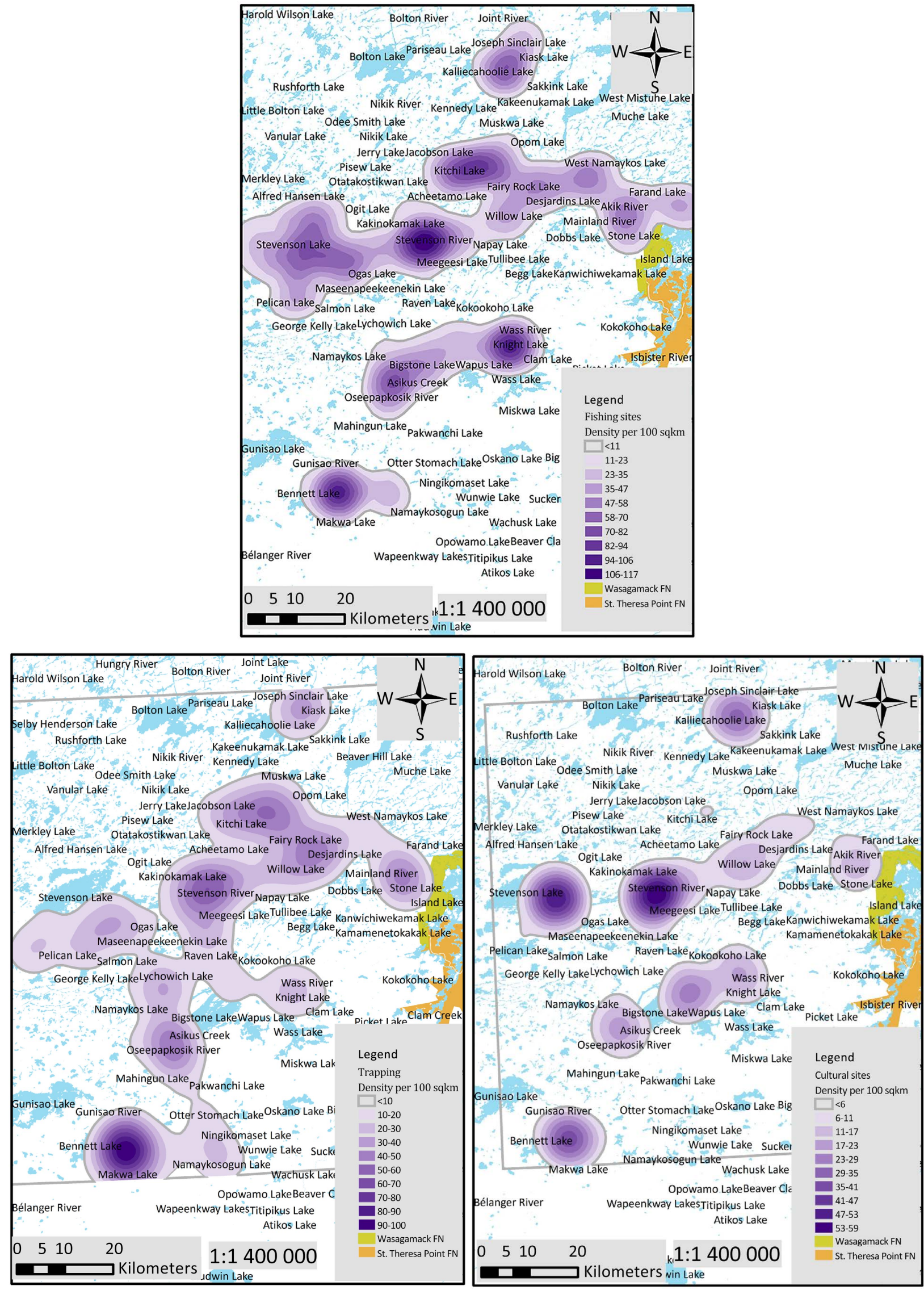

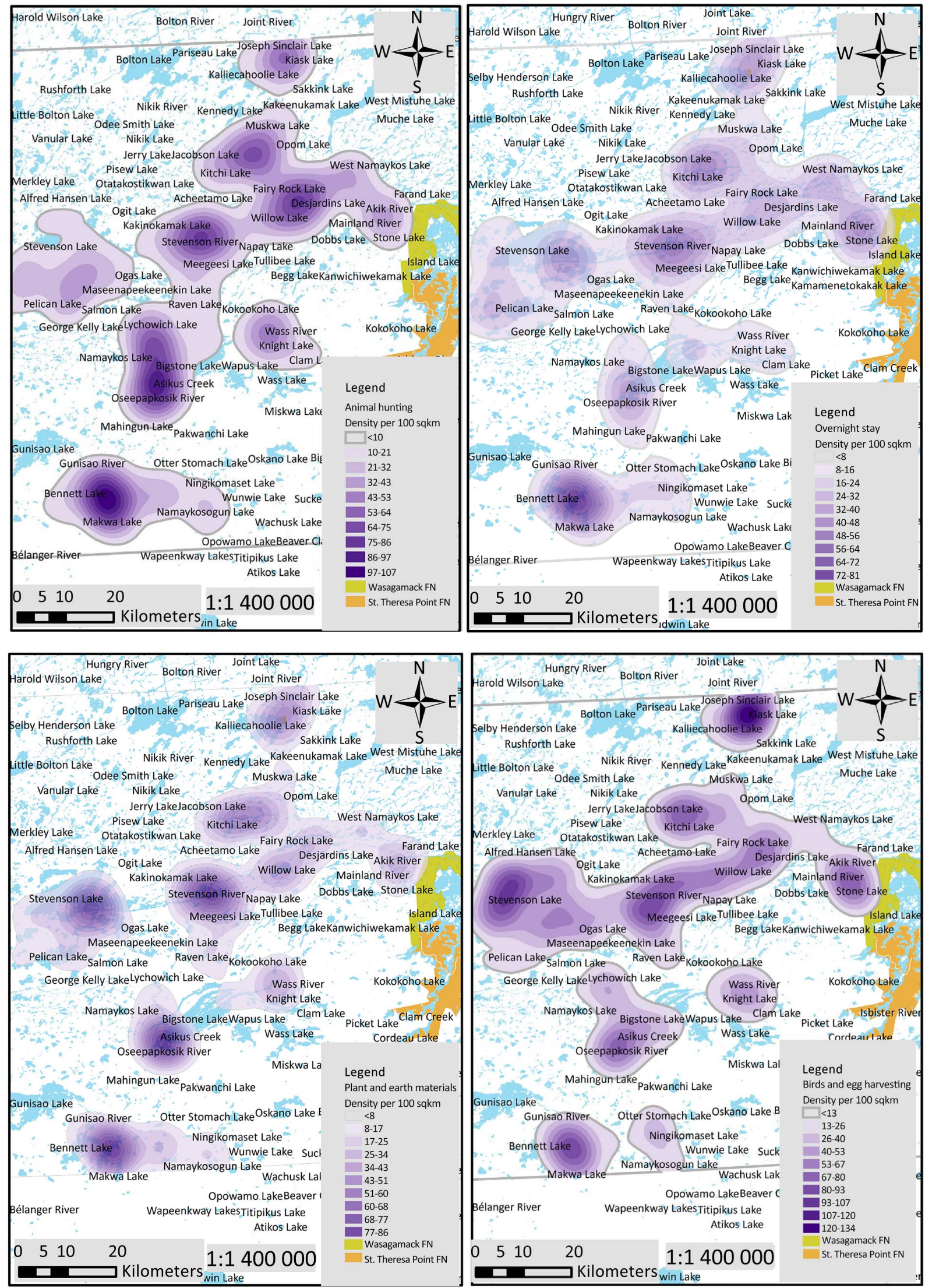

Figure 3. Thematic land use density of 49 harvesters of Wasagamack First Nation. 


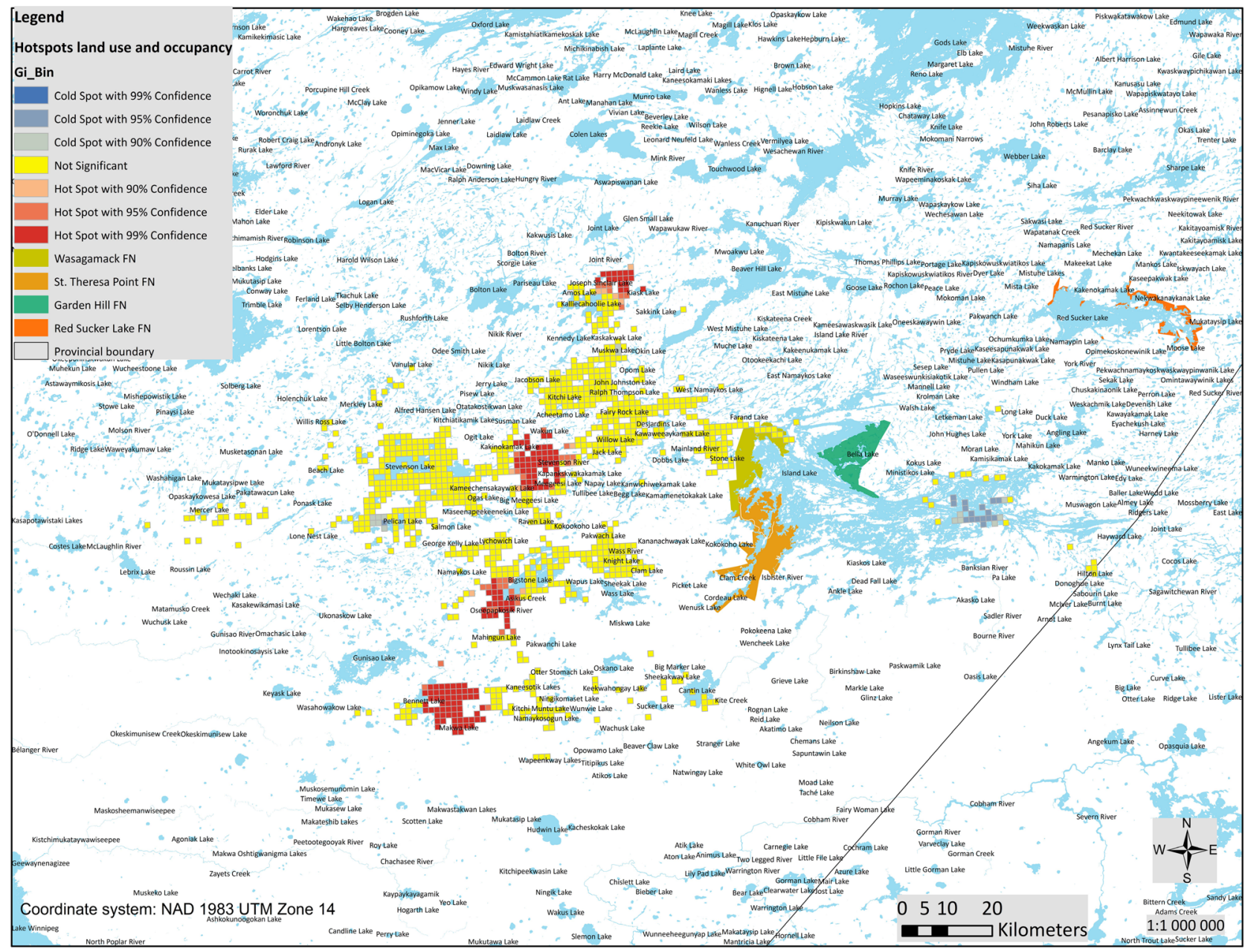

Figure 4. Land use hotspots of 49 harvesters of Wasagamack First Nation.

Overall, land use hotspot analysis showed 149 significant hotspots at the $99 \%$ confidence level, 36 significant hotspots at 95\% confidence level, and 11 hotspots at a $90 \%$ confidence level. We observed the statistically significant land use hotspots in and around Bennett Lake, Gunisao River, Makwa Lake, the area north of Makwa Lake and Namaykosogun Lake, as well as the areas of Mahingun Lake, Kaneesotik Lake, Wakun Lake, Stevenson River, Jack Lake, Deer Rapids, Strip Rapids, Wapaskank Narrows, Willow Lake, Kitchi Lake, Joseph Sinclair Lake, Namaykos Lake, and Kiask Lake. Hotspots were significant at the 95\% confidence level for fishing, trapping, hunting, bird/egg harvesting, and habitation, meaning that land uses are statistically significantly more concentrated in these areas. Statistically significant land use hotspots for fishing, trapping, and overnight stays observed in Bennett Lake, Gunisao River, and Makwa Lake for the 49 community members interviewed. Statistically significant hotspots for hunting were observed in Bigstone Lake, Stevenson River, and Oseepapkosik River; and for bird hunting and egg gathering, statistically significant hotspots were observed in, Kalliecahoolie Lake, Joseph Sinclair Lake, Namaykos Lake, and Kiask Lake. 


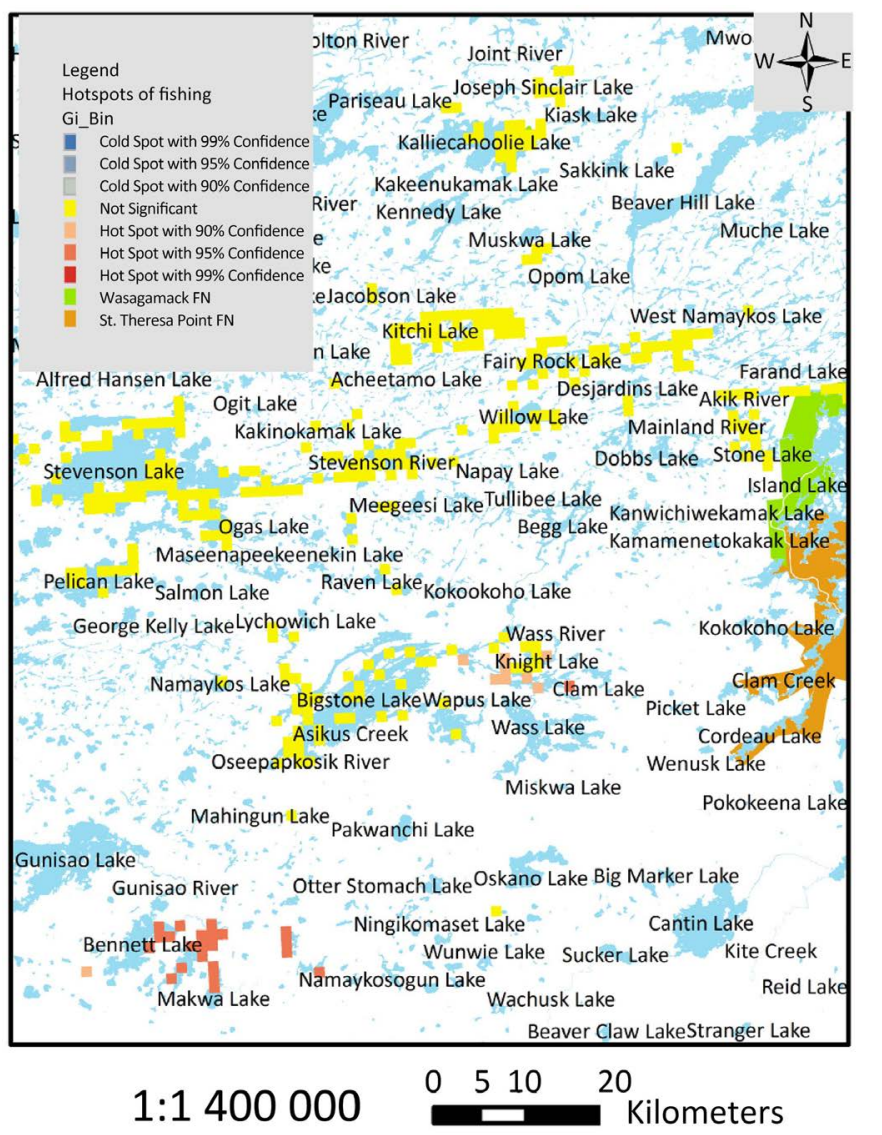

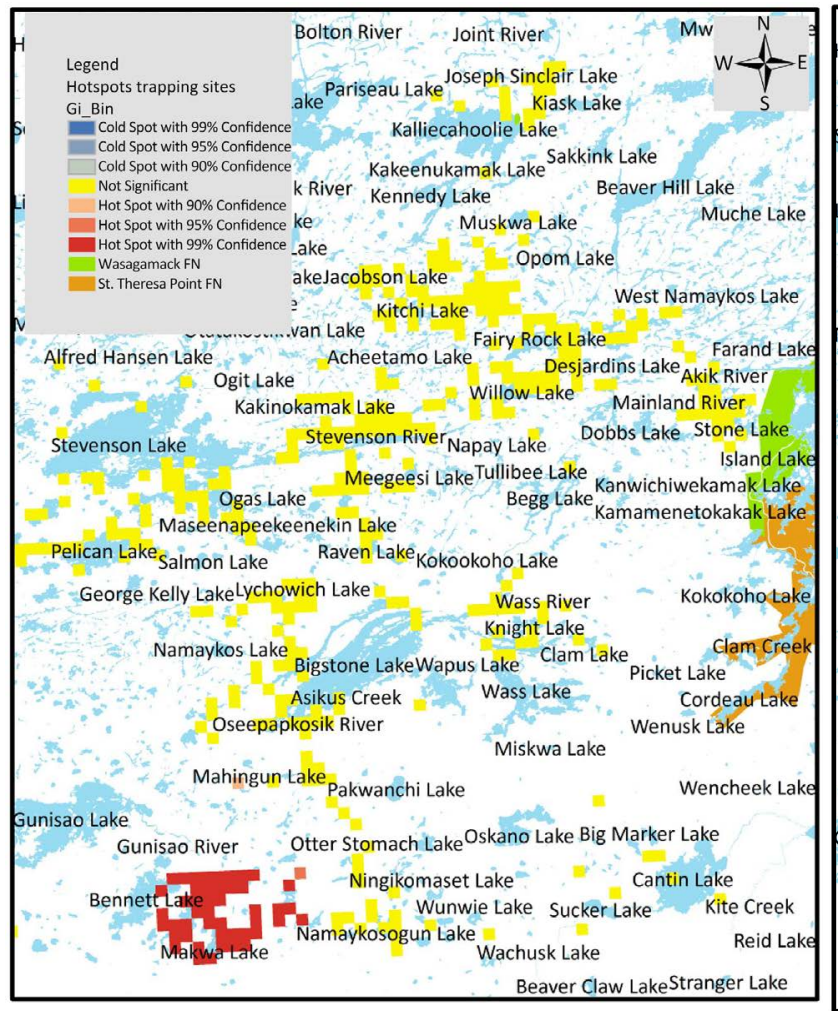

1:1 400000

$$
\begin{array}{llll}
0 & 5 & 10 & 20
\end{array}
$$

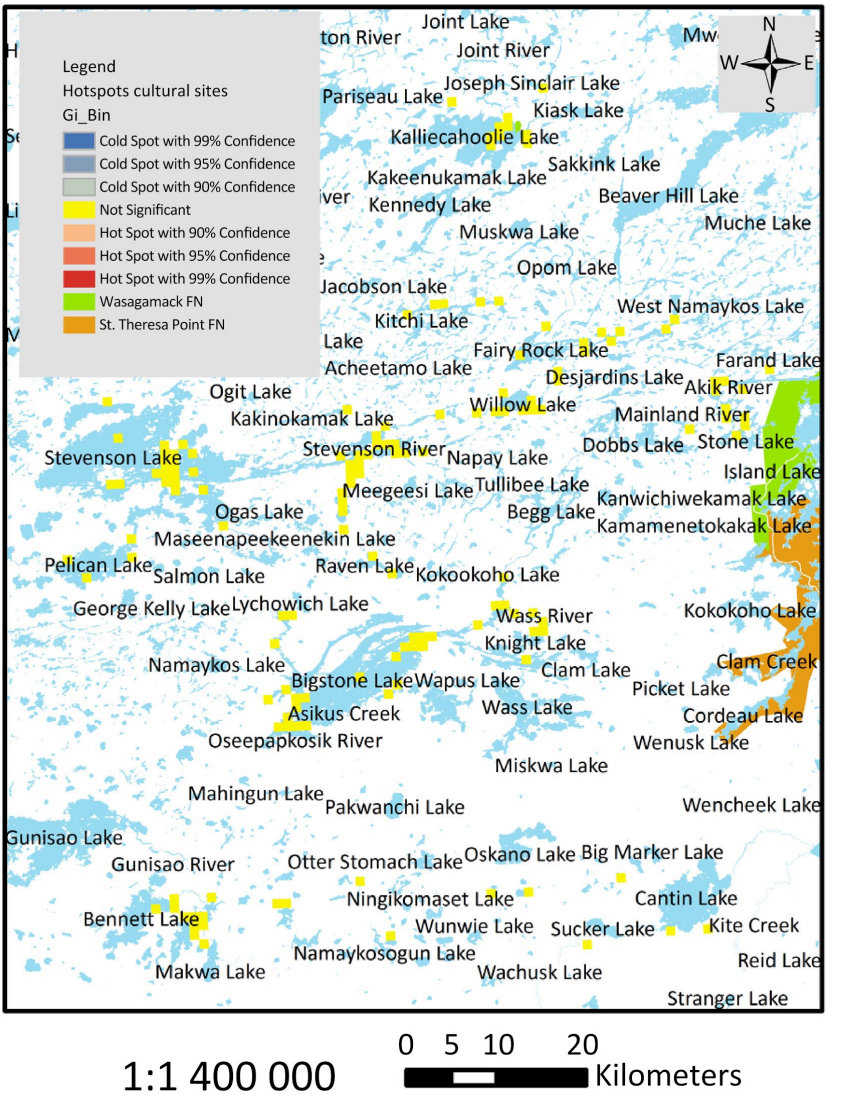




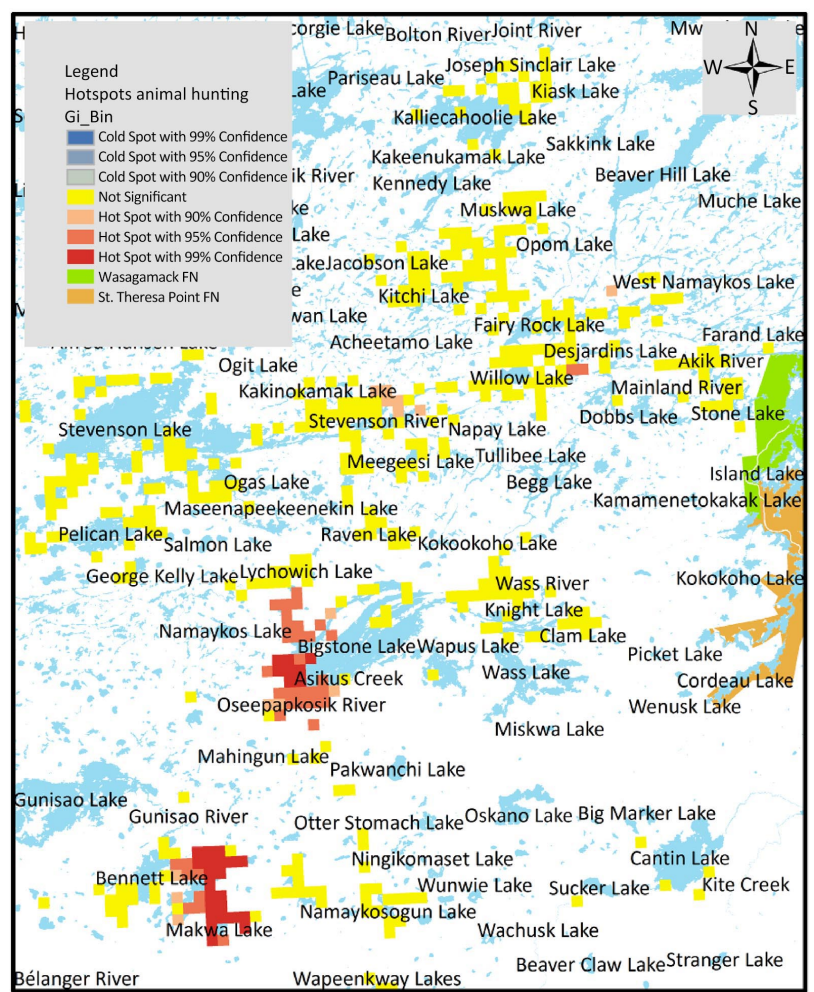

1:1 400000

\section{$\begin{array}{llll}0 & 5 & 10 & 20\end{array}$}

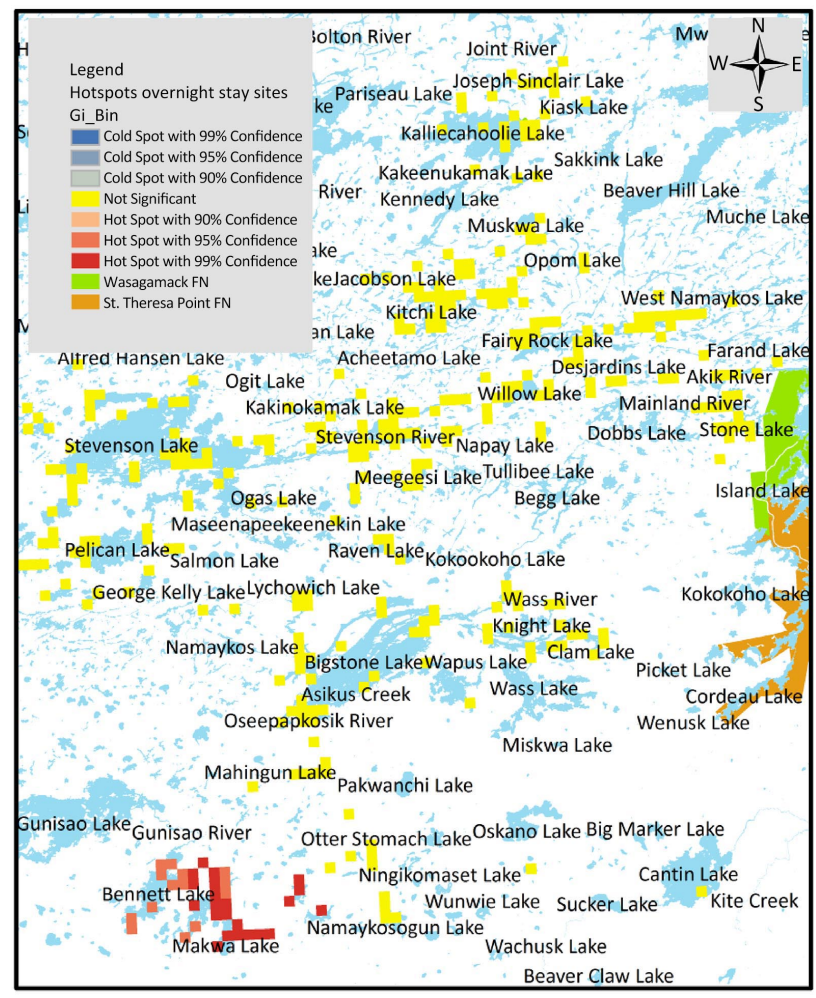

1:1 400000

\section{$\begin{array}{llll}0 & 5 & 10 & 20\end{array}$}

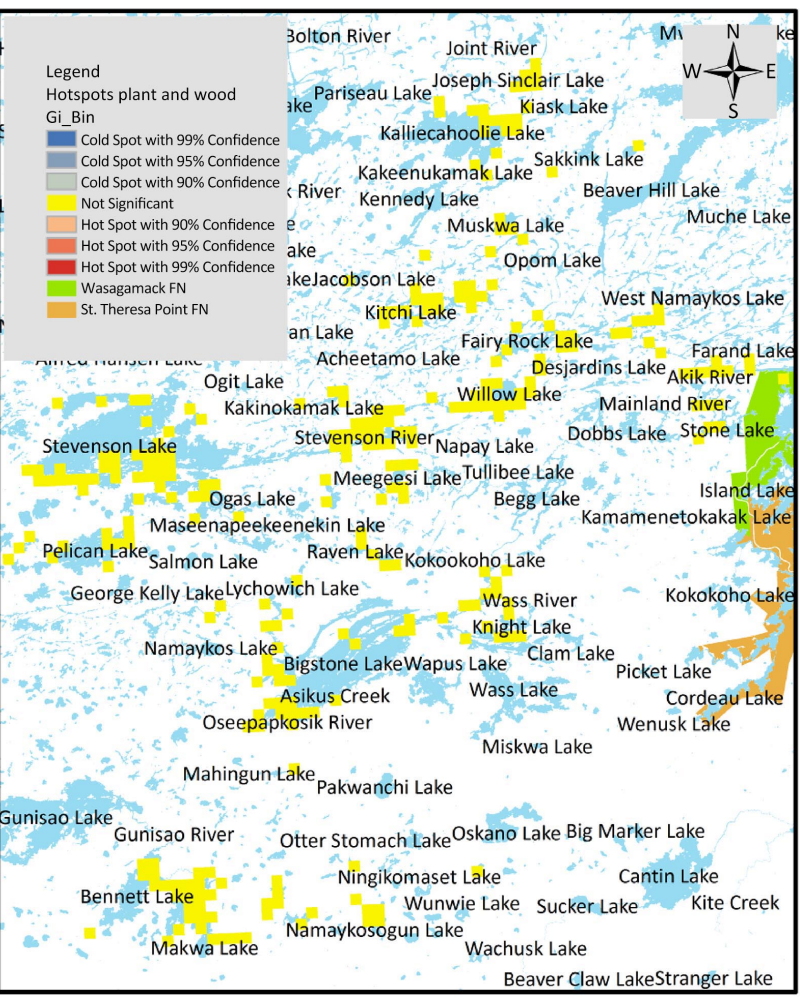

Beaver Claw LakeStranger Lake

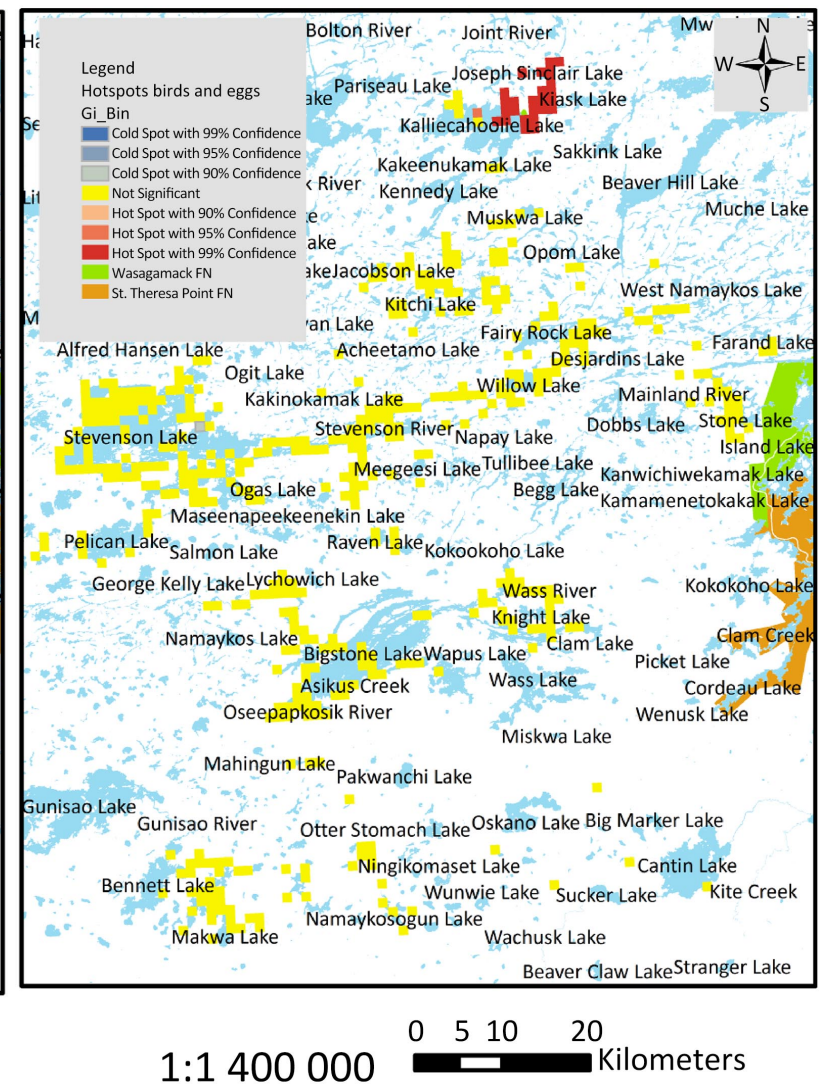

\section{1:1 400000}

$$
0 \quad 510 \quad 20
$$

Figure 5. Thematic land use and land use hotspots of 49 harvesters of Wasagamack First Na. 


\section{Discussion}

The density and hotspot maps provide a synopsis of the traditional territory and land use of 49 Wasagamack community members, by the intensity of uses. Density maps identified some areas in the traditional territory where the food harvesting and other land uses of 49 community members are concentrated. The land with higher land use densities are areas that community members prioritized in planning exercises for protection against mining exploration and extraction, hydropower construction, road construction, and other developmental threats. These are not the only sacred and well-used areas of the 49 community members used and occupied for their sustenance; they have walked, camped, feasted, and traveled vast distances beyond those areas through canoeing, dog sled, and snowshoeing. The actual land use and occupancy areas are much larger than documented and analyzed by the geographical information system (GIS) based approaches (Berkes et al., 1995; Thompson et al., 2019). Many indigenous leaders heavily criticize the limitations of only using GIS in understanding the Indigenous land use system without Indigenous viewpoints (McIlwraith \& Cormier, 2016).

Hotspot maps confirmed statistically significant land use areas. Statistical significance of land use depicts the clustering of land-use points is neither random nor by chance. Governments and non-Indigenous Peoples in Canada may think that Wasagamack Anishiniwuks are only using the land within the reserve area, so the land outside the reserve can be subject to government-led or approved development for the benefits of settler societies. However, the land use density and hotspot maps reinforce that Wasagamack Anishiniwuks used and occupied their entire traditional territory, many kilometers from the reserve, to fulfill their food, shelter, and cultural needs (Thompson, Thapa, \& Whiteway, 2019). This analysis rejects the colonial thought of occupying no man's land for the well-being of settler societies. The hotspot maps can support decision-making by Wasagamack First Nation to prioritize resource investment to protect their territory. For example, Wasagamack Chief and Council can prioritize its financial and human resources to minimize the threats against mining, hydro, logging, and infrastructure development on the land use hotspots. Wasagamack Chief and Council ultimately will focus on their priorities, but this land use data can help visualize the land-use.

Mainstream research in biodiversity and natural resources management interpret hotspots as the critical areas requiring governments to protect for species and their habitats in and around the significant hotspots (Cleasby et al., 2020; Gjerde et al., 2007; Naha et al., 2019), including against Indigenous occupancy. Usually, such recommendations are employed by the state and industry to work against the self-government of the land by Indigenous Peoples, thereby disrupting livelihoods and cultural continuity. Most of this mainstream science and management research is positivist and does not consider the colonial context and its research benefits in the research design and analysis. However, density 
and hotpot mapping of the land use of Wasagamack First Nation, including land use of many community members, can be used by Wasagamack First Nation to negotiate its ancestral territory for community protection and sustainable use (Norwegian \& Cizek, 2004). Rather than serving only the colonial government's interests, this research worked with the Indigenous People to document their land use to support their interests. The focus contrasts with the usual density and hotspot mapping studies that promote states' role in controlling the biodiversity hotspots. This paper uses the density and hotspot mapping approach to support the Wasagamack First Nation's goal of protecting their ancestral territory against developmental threats.

We interpret density and hotspots as significant areas for ensuring the food security and well-being of Indigenous communities. These ancestral lands were often priorities for preservation by the local community for future generations (Thompson et al., 2019). This research reinforces the significance of self-government and self-determination by Wasagamack First Nation to prioritize the protection of land and resources for community economic development (Mcilwraith \& Cormier, 2016; Palmater, 2019). We respect Wasagamack First Nation's right to self-determine their lands and territories. We also emphasize the significance of Elders and community members' knowledge and experience to plan and protect their land and territory. Developers and planners cannot wrongly interpret that the hotspot or density areas are the only places people use or the only land that needs community-led protection. Instead, the community views the entire area as sacred and needs protection against resource extraction and wants to sustain the wild food-based food system of Wasagamack First Nation. This analysis results from only a small sample of the population; thus, the findings cannot be generalized to the entire community. We also advise developers and planners not to use these maps to exploit Indigenous lands and resources. These maps are static and did not fully incorporate all the harvesters' data (Mcllwraith \& Cormier, 2016).

Indigenous landscapes are holistically connected rather than isolated spaces, as shown in a GIS map (McIlwraith \& Cormier, 2016). Sharon Mason, past chief of Wasagamack First Nation, described,

"Our DNA is in the land. We have got our people buried all over our traditional territory. And their DNA becomes part of the land ... We weren't just in one spot until we were put on that one spot [reserve]." Irrespective of the statistical significance of land use hotspots, Sharon's perspective emphasizes an intimate and spiritual connection of Wasagamack community members with their land and territory. This connection to land reinforces Indigenous philosophies of land and ancestral territories and justifies land protection by Indigenous communities used and occupied for generations (Tauli-Corpuz et al., 2018).

The entire ancestral land and territory of Indigenous peoples have cultural and sacred significance to the community and warrant protection (Joly et al., 2018). Lands that appear unoccupied in the maps could hold a community member's secret kept for fear of further colonization attempts by the govern- 
ments (Joly et al., 2018). Also, GIS mapping guided by the positivist research paradigm that focuses on a sample due to the limited research time and budget and generalizes the meaning for the entire population cannot adequately reflect how Indigenous Peoples used and occupied their territories. Integration of community members' perspective, such as that of Sharon, shows the significance of the ecological and cultural integrity of the ancestral land and territory of Wasagamack First Nation as their stories and experiences are much powerful than what can be presented in a GIS map. Mapping Indigenous territories become significant and meaningful to the respective Indigenous community/nation when the needs and interest of Indigenous communities guide the mapping process (Wojtuszewska, 2019). This research reinforces that the protection of the ecological and cultural integrity of the ancestral land and territory of Wasagamack First Nation requires the self-government and self-determination of Wasagamack First Nation at the scale of foodshed or watershed and collaborations among Indigenous nations.

\section{Policy Implication}

Protection of Indigenous land and waterbodies against industries and outsiders' development should be a key priority of the Manitoba government (Manitoba Indigenous and Northern Relations, 2018). At the federal and provincial levels, Canadian governments need to fully implement UNDRIP that the governments have ratified (Metis National Council, 2016; The Path to Reconciliation Act, 2016). So far, Canadian governments have failed to ensure self-determination and self-government of Indigenous Peoples in Canada adequately. For example, Lake Manitoba's 2011 artificial flooding reveals the Canadian governments' lack of commitment to securing Indigenous communities' inherent and livelihood rights. The displacement of Lake St. Martin First Nation from their reserve and territories in northern Manitoba symbolizes how the province undermined First Nation livelihoods by prioritizing settler development (Thompson et al., 2013). The underfunding of water infrastructure to meet the immediate needs of many First Nations in Canada, such as Garden Hill First Nation in Manitoba, reflects the unaccountability of Canadian governments to fulfill their obligation to meeting the fundamental human rights for Indigenous Peoples (Elash \& Walker, 2019; Palmater, 2019; Thompson, Bonnycastle, \& Hill, 2020). The continuation of resource extraction activities and pipelines in the Indigenous lands during the COVID 19 pandemic, which brought disease to these areas, shows how industries supported by government policy sacrifice Indigenous Peoples and their lands.

Conventional management approaches, such as the protected area approach or the resource development approach, do not address Indigenous communities' socio-cultural needs. Their worldview is against the Indigenous Peoples' view that ancestral land is sacred. Resource development in Indigenous territories would reduce biodiversity and peoples' access to lands (Jojola, 2013; Palmater, 
2019), thereby increasing risks of food scarcity, resource use conflict, and desecration of spiritual areas-overall, a picture of injustice (Tauli-Corpuz et al., 2018). Similarly, a protected area approach, unless carefully undertaken and devolved to First Nations, would reduce access to resources needed by First Nation communities and their role as stewards of the land (Zurba et al., 2019). Canada and Manitoba can learn from countries like Nepal to effectively design conservation areas and watersheds protected by community institutions and their governance mechanisms. These community-based conservation models refute the Eurocentric theory of the "tragedy of the commons" (Chaudhary et al., 2015) that still influences conservation programs in Europe and North America.

Community-based models and approaches contribute to local communities' ability to live a good life (i.e., Mino Bimaadiziwin), rather than this misapplied reference to the "tragedy of the commons". For example, the UNESCO World Heritage Centre has declared Pimachiowin Aki as the first Canadian mixed World Heritage site (UNESCO World Heritage Centre, 2018). Pimachiowin Aki covers the traditional territory of four Anishinaabe communities on the east side of Lake Winnipeg, Manitoba: Bloodvein River, Little Grand Rapids, Pauingassi, and Poplar River First Nations. The heritage site spans a boreal forest ecosystem of 2,904,000 hectares and is an Anishinaabe cultural landscape (UNESCO World Heritage Centre, 2018). A coordinating body, Pimachiowin Aki Corporation, with a management plan, has been formed by the First Nations and the provincial stakeholders to foster participatory governance of the heritage site (UNESCO World Heritage Centre, 2018). With this recognition, the area would be protected against external development threats, such as hydropower and mining. What remains unclear is how the heritage site will ensure the First Nations' Indigenous rights to their territories.

As Pimachiowin Aki is also a cultural heritage site under the operational guideline of World heritage sites' top-down governance model, its implementation process proceeds under state laws that treat Indigenous Peoples and local communities as partners only (UNESCO World Heritage Centre, 2017). However, in Canada's context, Indigenous Peoples need at least equal recognition as Canadian governments as the governments signed Treaties with Indigenous nations in equal standing. No colonial law outlaws the Treaties' effectiveness as the Treaties were to remain effective as long as the sun shines and rivers flow (Mercredi, 2012; Truth and Reconciliation Commission of Canada, 2015). Wasagamack First Nation and other First Nations in Island Lake might also be invited in the future to include their territories during the expansion of the area of Pimachiowin Aki. This research will empower Wasagamack First Nation to assert their claim on their territory's resources and governance; to the Canadian goverments, resource developers, and courts, this research provides an overview of the traditional territory that needs to be decolonized for Wasagamack First Nation. This land governance is central for Wasagamack's Mino Bimaadiziwin. 


\section{Conclusion}

The density and hotspot maps reinforce the importance of seeing the relationship between points rather than seeing unrelated individual harvest and cultural sites. Large areas of land are required to support traditional pursuits and Mino Bimaadiziwin. Indigenous Peoples have a relationship to the land and wildlife within a habitat, requiring a pristine foodshed and watershed for the abundance of wildlife. Indigenous territory for Wasagmack is vast, extending far beyond the reserve area and even Wasagamack's traplines to encompass a large area (Thompson et al., 2019).

The traditional territory is under the threat of resource extraction and other limits dictated by Canadian governments for land use by Wasagamack Anishiniwuk. However, according to the provincial law, the traplines and the overall ancestral territory, except for federal reserve land, are considered provincial Crown land. The provincial government retains jurisdictional authority over this region, promoting development activities that benefit the settler governments or settler-run industries (Palmater, 2019). The expansion of mining, hydroelectricity, road, and lumber into traditional territories, without adequate community consultation and against their wishes, undermine the sustainable livelihoods of the Wasagamack Anishiniwuk (Thompson et al., 2019). For example, the Manitoba (provincial) government has targeted the critical regions of Wasagamack First Nation's territory for mining and exploration, according to a recent bedrock mapping study finding of gold veins in the greenstone belt of Bigstone Lake and Knight Lake (Rinne, 2017). These lakes are statistically significant land use hotspots and are vital for Wasagamack Anishiniwuks to meet their food, shelter, and cultural needs. The bedrock mapping study does not mention any steps taken to consult Wasagamack community members, failing to acknowledge the significance of those areas for the livelihoods of Wasagamack First Nation.

To summarize, promoting settler-run protected areas or industrial development areas displacing Indigenous Peoples from their territory is a travesty to Indigenous communities (Jojola, 2013; Tauli-Corpuz et al., 2018; Thompson et al., 2019; Zurba et al., 2019). Land use planning in Indigenous territories needs to be led by Indigenous principles and values (Jojola, 2013) to identify community priorities. Meaningful participation of Indigenous community members and the integration of traditional knowledge in land use planning are required (Hostetler, 2018). Land use planning through this approach is critical to fulfilling Mino Bimaadiziwin.

This research contributes a new approach to traditional land use mapping through density and hotspot analysis, moving beyond point-based mapping to an area-based approach. This map displays ecologically and culturally significant areas in the ancestral territory of Wasagamack First Nation. Mainstream research uses hotspot mapping to identify the habitat areas that need the protection of threatened plants and animals with the establishment of protected areas (Gjerde et al., 2007), biological corridors, and early warning systems (Naha et al., 
2019). This method offers an approach that uses the critical point source data in a scientifically valid and repeatable process without releasing cultural point data that the community does not want to be shared. This method uses the highest quality of data that will stand up in court, considered point data of harvest sites (Tobias, 2010), and applies a scientific, repeatable method to develop area data. Thus, this method provides what the courts and industry want-a verifiable and valid methodology to show land-use and occupancy. At the same time, this technique provides First Nation communities to register their cultural and land-use data without exposing these sites for targeting or destruction of cultural artifacts.

Density and hotspot mapping combined with Indigenous community members' stories and perspectives identify land use areas of statistical significance. Density maps show the intensely used areas, not the specific points that many communities want to remain private, used by the community members. Hotspot maps cluster the land use locations to identify the hotspots, signifying the area's importance for Mino Bimaadiziwin. Through this approach, the communities could vividly defend against unwanted development and assert their jurisdiction on their ancestral land and territory.

This research found that land-use hotspots are statistically significant for bird hunting/egg gatherings in very different locations than other land uses. Why this occurred was not determined as doing so would require additional traditional ecological knowledge studies and analyses. Land and resources can change over time, impacting land use locations, densities, and significant hotspots (Joly et al., 2018). Consequently, land use mapping and documentation of traditional knowledge associated with land use over time and space can better inform planning and sustainable territorial governance by Wasagamack First Nation.

We hope these maps, guided from Indigenous worldviews and epistemologies, will provide a basis for protecting traditional land uses of Wasagamack Anishiniwuks and a method for other communities to apply. These maps, with Elders' teachings, will inform youth about their traditional territory. Also, density and hotspot maps provide a base for future Indigenous land use planning (Manitoba Indigenous and Northern Relations, 2018; Thompson et al., 2019). This traditional land-use documentation provides another tool to fight for Indigenous self-government and self-determination by Indigenous Peoples on Turtle Island.

\section{Acknowledgements}

We would like to thank the 49 harvesters of Wasagamack First Nation for sharing their knowledge. Also, we thank the Chief and Council of Wasagamack First Nation for approving this research. The funding support was provided by the Social Science and Humanity Research Council (SSHRC) funded Mino Bimaadiziwin Partnership: Reconciliation in Action, University of Manitoba Graduate Fellowship, \& Karen Palidwor Memorial Fellowship in Forest and Wildlife Management. 


\section{Conflicts of Interest}

The authors declare no conflicts of interest regarding the publication of this paper.

\section{References}

Ballard, M., Coughlin, J., \& Martin, D. (2019). Reconciling with Minoaywin: First Nations Elders' Advice to Promote Healing from Forced Displacement. Canadian Journal on Aging, 39, 169-177. https://doi.org/10.1017/S0714980819000412

Berkes, F., Hughes, A., George, P. J., Preston, R. J., Cummins, B. D., \& Turner, J. (1995). The Persistence of Aboriginal Land Use: Fish and Wildlife Harvest Areas in the Hudson and James Bay Lowland, Ontario. Arctic, 48, 81-93.

https://doi.org/10.14430/arctic1227

Booth, A. L., \& Skelton, N. W. (2004). First Nations Access and Rights to Resources. In B. Mitchell (Ed.), Resource and Environmental Management in Canada: Addressing Conflict and Uncertainty (3rd ed., pp. 80-103). Oxford: Oxford University Press.

Borrows, J. J., \& Rotman, L. I. (2018). Aboriginal Legal Issues: Cases, Materials \& Commentary (5th ed.). Canada: LexisNexis.

Canada Royal Commission on Aboriginal Peoples (1996a). Volume 1. Looking Forward, Looking Back.

https:/qspace.library.queensu.ca/bitstream/handle/1974/6874/RRCAP1_combined.pdf ?sequence $=5$ \&isAllowed $=\mathrm{y}$

Canada Royal Commission on Aboriginal Peoples (1996b). Volume 5. Renewal: A Twenty-Year Commitment.

https://qspace.library.queensu.ca/bitstream/handle/1974/6874/RRCAP5_combined.pdf ?sequence $=1$ \&isAllowed $=\mathrm{y}$

CEHI (2018a). Introduction to Hotspot Analysis (p. 9). Children's Environmental Health Initiative.

https://www.cdc.gov/dhdsp/maps/GISX/training/module3/files/3_hotspot_analysis_m odule.PDF

CEHI (2018b). Spatial Analyst Tools (p. 17). Children's Environmental Health Initiative. https://www.cdc.gov/dhdsp/maps/gisx/training/module3/files/2_spatial_analyst_modul e.pdf

Chaudhary, P., Chhetri, N. B., Dorman, B., Gegg, T., Rana, R. B., Shrestha, M., Thapa, K., Lamsal, K., \& Thapa, S. (2015). Turning Conflict into Collaboration in Managing Commons: A Case of Rupa Lake Watershed, Nepal. International Journal of the Commons, 9, 744-771. https://doi.org/10.18352/ijc.561

Cleasby, I. R., Owen, E., Wilson, L., Wakefield, E. D., O’Connell, P., \& Bolton, M. (2020). Identifying Important At-Sea Areas for Seabirds Using Species Distribution Models and Hotspot Mapping. Biological Conservation, 241, Article ID: 108375.

https://doi.org/10.1016/j.biocon.2019.108375

Collins, J., \& Thompson, W. K. (2017). Reconciliation in Australia? Dreaming beyond the Cult of Forgetfulness. In B. Jenkins, D. B. Subedi, \& K. Jenkins (Eds.), Reconciliation in Conflict-Affected Communities: Practices and Insights from the Asia-Pacific (pp. 185-205). Singapore: Springer. https://doi.org/10.1007/978-981-10-6800-3_11

Craft, A. (2011). Treaty interpretation-A Tale of Two Stories. In A. Craft (Ed.), Breathing Life into the Stone Fort Treaty. Vancouver: University of Victoria. https://ssrn.com/abstract $=3433842$

Department of Justice Canada (2018). Principles: Respecting the Government of Canada's 
Relationship with Indigenous Peoples. Her Majesty the Queen in Right of Canada. https://www.justice.gc.ca/eng/csj-sjc/principles.pdf

Elash, A., \& Walker, C. (2019, January 29). Ottawa to Examine First Nation's Water System after Residents Voice Concerns. CBC News.

https://www.cbc.ca/news/indigenous/garden-hill-first-nation-water-feasibility-study-1. $\underline{4994175}$

ESRI (2016). Understanding Density Analysis.

http://desktop.arcgis.com/en/arcmap/10.3/tools/spatial-analyst-toolbox/understanding -density-analysis.htm

Fallding, H. (2010, November 6). The Worst of the Bargain-Island Lake Residents Still Waiting for So-Called Treaty Benefits. Winnipeg: Winnipeg Free Press.

https://www.winnipegfreepress.com/no-running-water/how/island-lake-residents-stillwaiting-for-so-called-treaty-benefits-the-worst-of-the-bargain-106814213.html

Freeman, M. M. R. (2011). Looking Back-and Looking Ahead-35 Years after the Inuit Land Use and Occupancy Project. Canadian Geographer, 55, 20-31.

https://doi.org/10.1111/j.1541-0064.2010.00341.x

Gjerde, I., Saetersdal, M., \& Blom, H. H. (2007). Complementary Hotspot Inventory-A Method for Identification of Important Areas for Biodiversity at the Forest Stand Level. Biological Conservation, 137, 549-557. https://doi.org/10.1016/j.biocon.2007.03.007

Government of Canada (2017). Speech for the Honourable Carolyn Bennett, Minister of Indigenous and Northern Affairs at the United Nations Permanent Forum on Indigenous Issues 16th Session.

https://www.canada.ca/en/indigenous-northern-affairs/news/2017/05/speaking_notes_ forthehonourablecarolynbennettministerofindigenou.html

Hostetler, G. (2018). Conceptualizing Natural Resource and Environmental Management as Deliberative Democratic Practice: Land Use Planning on the East Side of Lake Winnipeg, Manitoba, 2000-2013. Doctoral Dissertation, Winnipeg, MB: University of Manitoba. https://mspace.lib.umanitoba.ca/handle/1993/32987

Imbong, R. A. (2018). Neoliberalism and the Moro Struggle in Southern Philippines. Journal for the Study of Religions and Ideologies, 17, 61-84. http://jsri.ro/ojs/index.php/jsri/article/view/1000

Indian and Northern Affairs Canada (1969). Treaty 5 between Her Majesty the Queen and the Saulteaux and Swampy Cree Tribes of Indians at Beren's River and Norway House with Adhesions.

http://www.trcm.ca/wp-content/uploads/PDFsTreaties/Treaty\%205\%20Text\%20and\% 20Adhesions.pdf

Jane, M., McCallum, L., \& Perry, A. (2018). Structures of Indifference: An Indigenous Life and Death in a Canadian City. Winnipeg, MB: University of Manitoba Press.

Jojola, T. (2013). Indigenous Planning: Towards a Seven Generations Model. In D. C. Natcher, R. Walker, \& T. Jojola (Eds.), Reclaiming Indigenous Planning (pp. 457-472). Montreal, Quebec: McGill-Queen's University Press.

Joly, T. L., Longley, H., Wells, C., \& Gerbrandt, J. (2018). Ethnographic Refusal in Traditional Land Use Mapping: Consultation, Impact Assessment, and Sovereignty in the Athabasca Oil Sands Region. The Extractive Industries and Society, 5, 335-343. https://doi.org/10.1016/j.exis.2018.03.002

Joseph, B. (2018). 21 Things You May Not Know about the Indian Act (1st ed.). Port Coquitlam, BC: Indigenous Relations Press.

Kovach, M. (2009). Indigenous Methodologies: Characteristics, Conversations, and Contexts. Toronto: University of Toronto Press. 
Krisp, J. M., Peters, S., \& Murphy, C. E. (2009). Visual Bandwidth Selection for Kernel Density Maps. Photogrammetrie-Fernerkundung-Geoinformation, 2009, 445-454. https://doi.org/10.1127/1432-8364/2009/0032

Lambert, L. (2014). Research for Indigenous Survival: Indigenous Research Methodologies in the Behavioural Sciences. Lincoln, NE: University of Nebraska Press.

Library and Archives Canada (2015). Maps: 1667-1999.

http://www.bac-lac.gc.ca/eng/discover/politics-government/canadian-confederation/Pa ges/maps-1667-1999.aspx

Manitoba Indigenous and Northern Relations (2018). What We Heard: 2017 Manitoba Land Use Planning Gathering, Conference and Trade Show Summary Report. https://www.gov.mb.ca/inr/resources/pubs/inr-land-use-tradeshow-summary-report.p df

McGregor, D. (2018). Reconciliation and Environmental Justice. Journal of Global Ethics, 14, 222-231. https://doi.org/10.1080/17449626.2018.1507005

McIlwraith, T., \& Cormier, R. (2016). Making Place for Space: Land Use and Occupancy Studies, Counter-Mapping, and the Supreme Court of Canada's Tsilhqot'in Decision. BC Studies, 188, 35-53.

https://www.researchgate.net/publication/279176871_Making_Place_for_Space_Land_ Use_and_Occupancy_Studies_Counter-Mapping_and_the_Supreme_Court_of_Canad a\%27s_Tsilhqot\%27in_Decision

Mercredi, O. (2012). Speaking Notes Transcript. Crown-First Nations Gathering. http://www.afn.ca/uploads/files/cfngchiefmercredispeakingnotes.pdf

Metis National Council (2016). Speaking Notes for the Honourable Carolyn Bennett, Minister of Indigenous and Northern Affairs: Announcement of Canada's Support for the United Nations Declaration on the Rights of Indigenous Peoples, United Nations Permanent Forum on Indigenous Issues.

http://www.metisnation.ca/wp-content/uploads/2016/05/Speech-Minister-Bennett-UN PFII-NEW-YORK-MAY-10-FINAL.pdf

Naha, D., Sathyakumar, S., Dash, S., Chettri, A., \& Rawat, G. S. (2019). Assessment and Prediction of Spatial Patterns of Human-Elephant Conflicts in Changing Land Cover Scenarios of a Human-Dominated Landscape in North Bengal. PLOS ONE, 14, e0210580. https://doi.org/10.1371/journal.pone.0210580

National Energy Board (2018). Canada's Energy Future 2018: Energy Supply and Demand Projections to 2040. https://www.cer-rec.gc.ca/nrg/ntgrtd/ftr/2018/pblctn-eng.html

Norwegian, H., \& Cizek, P. (2004). Using Land Use and Occupancy Mapping and GIS to Establish a Protected Area Network in the Deh Cho Territory. Deh Cho First Nations. http://www.iapad.org/wp-content/uploads/2015/07/04_03_22_land_use_paper_norweg ian_and_cizek.pdf

Olson, R., Hackett, J., \& DeRoy, S. (2016). Mapping the Digital Terrain: Towards Indigenous Geographic Information and Spatial Data Quality Indicators for Indigenous Knowledge and Traditional Land-Use Data Collection. The Cartographic Journal, 53, 348-355. https://doi.org/10.1080/00087041.2016.1190146

Palmater, P. (2019, February 6). First Nations Water Problems: A Crisis of Canada's Own Making. Policy Options.

https://policyoptions.irpp.org/magazines/february-2019/first-nations-water-problemscrisis-canadas-making/

Prasannakumar, V., Vijith, H., Charutha, R., \& Geetha, N. (2011). Spatio-Temporal Clus- 
tering of Road Accidents: GIS Based Analysis and Assessment. Procedia-Social and Behavioral Sciences, 21, 317-325.

https://doi.org/10.1016/j.sbspro.2011.07.020

Reynar, A., \& Matties, Z. (2015). Indigenous People of Manitoba: A Guide for Newcomers.

https://www.immigratemanitoba.com/wp-content/uploads/2016/07/indigenousguideweb-version2b.pdf

Rinne, M. L. (2017). Preliminary Results of Bedrock Mapping at Bigstone Lake and Knight Lake, Northwestern Superior Province, Manitoba (Parts of NTS 53E11, 12, 13, 14) (pp. 19-29). Report of Activities 2017, Manitoba Growth, Enterprise and Trade, Manitoba Geological Survey.

https://www.manitoba.ca/iem/geo/field/roa17pdfs/GS2017-3.pdf

Shafabakhsh, G. A., Famili, A., \& Bahadori, M. S. (2017). GIS-Based Spatial Analysis of Urban Traffic Accidents: Case Study in Mashhad, Iran. Journal of Traffic and Transportation Engineering (English Edition), 4, 290-299. https://doi.org/10.1016/j.jtte.2017.05.005

Simura, B., \& Mudimu, G. T. (2019). Consequences of Elitist Reconciliation in Zimbabwe and South Africa: A Comparative Study. Journal of Social Sciences, 58, 13-23. https://doi.org/10.31901/24566756.2019/58.1-3.2230

Smith, L. (2001). Decolonizing Methodologies (4th ed.). London: Zed Books Ltd.

StatsCanada (2017). Census Profile, 2016 Census-Wasagamack, Indian Reserve [Census Subdivision], Manitoba and Division No. 22, Census Division [Census Division], Manitoba. Statistics Canada.

http://www12.statcan.gc.ca/census-recensement/2016/dp-pd/prof/details/page.cfm?Lan $\mathrm{g}=\mathrm{E} \& \mathrm{Geo} 1=\mathrm{CSD} \& \mathrm{Code} 1=4622800 \& \mathrm{Geo} 2=\mathrm{CD} \& \mathrm{Code} 2=4622 \& \mathrm{Data}=$ Count $\&$ SearchTe $\underline{\mathrm{xt}=\text { Wasagamack } \& \text { SearchType }=\text { Begins } \& \text { SearchPR }=01 \& \mathrm{~B} 1=\mathrm{All} \& \mathrm{TABID}=1}$

Tauli-Corpuz, V., Alcorn, J., \& Molnar, A. (2018). Cornered by Protected Areas: Replacing "Fortress" Conservation with Rights-Based Approaches Helps Bring Justice for Indigenous Peoples and Local Communities, Reduces Conflict, and Enables Cost-Effective Conservation and Climate Action.

https://rightsandresources.org/wp-content/uploads/2018/06/Cornered-by-PAs-Brief_R RI_June-2018.pdf

Thapa, K. (2018). Indigenous Land Rights and Indigenous Land Use Planning: Exploring the Relevance and Significance to Wasagamack First Nation, Northern Manitoba, Canada. MNRM Dissertation, Winnipeg, MB: University of Manitoba.

https://mspace.lib.umanitoba.ca/handle/1993/33359

The Crown Lands Act, C.C.S.M. c. C340 (1987).

http://web2.gov.mb.ca/laws/statutes/ccsm/_pdf.php?cap=c340

The Mines and Minerals Act, C.C.S.M. c. M162 (1991).

http://web2.gov.mb.ca/laws/statutes/ccsm/_pdf.php?cap=m162

The Path to Reconciliation Act, S.M. c. 5 (2016).

https://web2.gov.mb.ca/bills/40-5/pdf/b018.pdf

The Planning Act, C.C.S.M. c. P80 (2005).

https://web2.gov.mb.ca/laws/statutes/ccsm/p080e.php

The Planning Act, C.C.S.M. c. P80 Provincial Planning Regulation (2011).

https://web2.gov.mb.ca/laws/regs/current/081.11.pdf

Thompson, S., Ballard, M., \& Martin, D. (2013). Lake St. Martin First Nation Community Members' Experiences of Induced Displacement: “We're Like Refugees”. Refuge, 29, 
75-86. https://doi.org/10.25071/1920-7336.38168

Thompson, S., Bonnycastle, M., \& Hill, S. (2020, April 28). "Wash Hands Frequently” and "Self-Isolate" for COVID-19 Are Akin to "Let Them Eat Cake" in Manitoba First Nations with Overcrowded Homes Lacking Piped Water. Mino Bimaadiziwin Partnership: Reconciliation in Action.

http://ecohealthcircle.com/wash-hands-frequently-and-self-isolate-for-covid-19-are-ak in-to-let-them-eat-cake-in-manitoba-first-nations-with-overcrowded-homes-lacking-p iped-w/\#_ftnref1

Thompson, S., Harper, V., \& Whiteway, N. (2020). Keeping Our Land the Way the Creator Taught Us: Wasagamack First Nation. Manitoba First Nations Education Resource Centre.

Thompson, S., Pritty, P., \& Thapa, K. (2020). Eco-Carnivorism in Garden Hill First Nation. In R. M. Katz-Rosene, \& S. J. Martin (Eds.), GREEN MEAT? Sustaining Eaters, Animals, and the Planet (pp. 107-132). Montreal, Quebec: McGill-Queen's University Press.

Thompson, S., Thapa, K., \& Whiteway, N. (2019). Sacred Harvest, Sacred Place: Mapping Harvesting Sites in Wasagamack First Nation. Journal of Agriculture, Food Systems, and Community Development, 9, 251-279. https://doi.org/10.5304/jafscd.2019.09B.017

Tobias, T. (2010). Living Proof: The Essential Data-Collection Guide for Indigenous Use-and-Occupancy Map Surveys. Union of BC Indian Chiefs and Ecotrust Canada.

Truth and Reconciliation Commission of Canada (2015). Honouring the Truth, Reconciling for the Future: Summary of the Final Report of the Truth and Reconciliation Commission of Canada.

http://www.trc.ca/assets/pdf/Honouring_the_Truth_Reconciling_for_the_Future_July 23_2015.pdf

Tsuji, L. J. S., Manson, H., Wainman, B. C., Vanspronsen, E. P., Shecapio-Blacksmith, J., Rabbitskin, T., Tsuji, L. J. S., Manson, H., Vanspronsen, E. P., Wainman, B. C., Shecapio-Blacksmith, J., \& Rabbitskin, T. (2007). Identifying Potential Receptors and Routes of Contaminant Exposure in the Traditional Territory of the Ouje-Bougoumou Cree: Land Use and a Geographical Information System. Environmental Monitoring and Assessment, 127, 293-306. https://doi.org/10.1007/s10661-006-9280-Z

Tully, J. (1999). Aboriginal Peoples: Negotiating Reconciliation. In J. Bickerton, \& A.-G. Gagnon (Eds.), Canadian Politics (3rd ed., pp. 423-442). Peterborough: Broadview Press, Ltd.

UNESCO World Heritage Centre (2017). UNESCO World Heritage Centre-The Operational Guidelines for the Implementation of the World Heritage Convention (p. 172). UNESCO World Heritage Centre. https://whc.unesco.org/en/guidelines/

UNESCO World Heritage Centre (2018). Decision-42 COM 8B.11: Pimachiowin Aki (Canada). https://whc.unesco.org/en/decisions/7124

United Nations (2008). United Nations Declaration on the Rights of Indigenous Peoples. http://www.un.org/esa/socdev/unpfii/documents/DRIPS_en.pdf

Wasagamack First Nation (2010). The Way It Was (p. 41). Manitoba First Nations Education Resource Centre.

Wilson, S. (2008). Research Is Ceremony: Indigenous Research Methods. Nova Scotia: Fernwood Publishing.

Wojtuszewska, V. (2019). On the Importance of Language: Reclaiming Indigenous Place Names at Wasagamack $\triangleleft \cdot S b L \times$ First Nation, Manitoba, Canada. MNRM Dissertation, Winnipeg, MB: University of Manitoba. 
https://mspace.lib.umanitoba.ca/handle/1993/33841

Zurba, M., Beazley, K. F., English, E., \& Buchmann-Duck, J. (2019). Indigenous Protected and Conserved Areas (IPCAs), Aichi Target 11 and Canada's Pathway to Target 1: Focusing Conservation on Reconciliation. Land, 8, 10.

https://doi.org/10.3390/land8010010 